\title{
Transatlantica
}

Revue d'études américaines. American Studies Journal

\section{Fifteen Questions to Jean Kempf}

\section{Victoria Amador}

\section{(2) OpenEdition}

\section{Journals}

\section{Electronic version}

URL: https://journals.openedition.org/transatlantica/6750

DOI: 10.4000/transatlantica. 6750

ISSN: $1765-2766$

\section{Publisher}

Association française d'Etudes Américaines (AFEA)

\section{Printed version}

Date of publication: 31 December 2013

\section{Electronic reference}

Victoria Amador, "Fifteen Questions to Jean Kempf", Transatlantica [Online], 2 | 2013, Online since 09

May 2014, connection on 02 February 2023. URL: http://journals.openedition.org/transatlantica/6750 ; DOI: https://doi.org/10.4000/transatlantica.6750

This text was automatically generated on 2 February 2023.

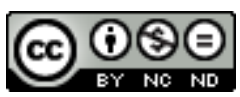

Creative Commons - Attribution-NonCommercial-NoDerivatives 4.0 International - CC BY-NC-ND 4.0 https://creativecommons.org/licenses/by-nc-nd/4.0/ 


\title{
Fifteen Questions to Jean Kempf
}

\author{
Victoria Amador
}

1 Jean Kempf is a professor of American Studies at the University Lumière-Lyon. He has written extensively on American photography and on American cultural history.

Most of the pictures in the exhibition of his photographs at the conference "Survivance des icônes: usage et recyclage des figures et emblèmes culturels ( $\mathrm{xx}^{\mathrm{e}}-\mathrm{xxI}^{\mathrm{e}}$ siècles), cochaired by Géraldine Chouard (University Paris-Dauphine) and Déborah Lévy-Bertherat (ENS Ulm) were made during an extended stay in 2012-2014 as a research professor in New York, on an appointment from the French National Center of Scientific Research (CNRS). Jean Kempf very kindly answered the following questions via e-mail correspondence with Victoria Amador.

What elements of American life in terms of iconography do you find particularly intriguing in terms of your photography?

This is a very hard but central question. Obviously American cities offer the photographer an amazing "reservoir" of scenes. They are a constant source of quasisurrealistic encounters and that has fascinated photographers (but not only) for a long, long time. I'm much less interested in the American landscape, in its traditional form at least, although it is a potent source of iconography for many.

Like many other photographers, I'm fascinated by the hand of man on the land, and by its palimpsestic effect, something I feel is nowhere more visible than in the US. That is, by the way, a rebuttal of the idea that the country has no history. It may have a short history but it's everywhere visible as process, as a dynamic, and sometimes as a painful encounter. There is a form of anarchism in the American space which never ceases to fascinate me.

Who have your major influences been, both as a younger photographer and currently? How old were you when you began photographing?

I've been taking pictures seriously since I was 14 or 15 . At the time I even considered a career as a photographer, going to photography school (there was basically only one in France at the time and it was only technical), and perhaps working for the press or as a documentarian for an agency, which were flourishing at the time (early 70s). I traveled to Canada (Ottawa) to do my junior year abroad, and I happened to be 
hired as a photographer by a semi-professional student paper run by the Carleton University journalism students. I met an incredibly talented bunch of students there; some of them are still friends today.

For various reasons I then veered towards academia, and decided to do a Ph.D. on a photographic topic (it was the photos of the FSA [Farm Security Administration], then largely understudied). As I wrote more and more about photography I stopped actually taking pictures, as if the two activities seemed incompatible. I never quite stopped, however, but only started doing it seriously again well into my 30s and especially after the advent of digital photography, which really changed my life.

In terms of influences, it's actually pretty simple. When I was a teenager it was definitely Henri Cartier-Bresson, like so many of my generation. He was the ultimate street photographer and the ultimate cool man. Also, he was one of the few photographers you could see pictures by at a time when there were hardly any exhibitions, at least in the provinces where I lived, and very few photo books either. Actually my second scholarly article was about him and was entitled: "HCB or how to kill the father"!

Today, it's much more difficult to say, as my photographic culture is so much broader. I'd say that the Walker Evans of the 1920-30s and the Robert Frank of The Americans (what they did afterwards I don't find too inspiring)-both of whom I studied academically-are still very much part of my "eye" and mind. But I'd add Bruce Davidson, probably one of the greatest photographers alive, and just to add a little snobbish touch, Tony Ray-Jones, who died very young but left an impressive body of work.

What is your answer to those who think photography is somehow a lesser art form because it's just taking pictures?

Well, I have two answers to that. One is yes, but who cares? It's all the better if anyone can do it. It's a truly democratic art that can be practiced at various levels of complexities (try that with music and you'll see!).

My other is a little different and goes like this: anyone can take one picture, two pictures, ten pictures which will be interesting and perhaps even very good. But the "art of photography" reveals itself in a long-term oeuvre, and also for reportage it's about telling stories. And that is damn difficult!

Now if you ask me about the art market, that's a whole different ball game. I think photographers should be able to make a good living, especially documentarians who at the moment are dying in poverty, but the notion of selling a picture for millions, as is the case for a small number of living contemporary photographers, is obscene.

What types of cameras and lenses do you use?

When I was younger I worked with Pentax Spotmatics. They were incredibly sturdy cameras with amazing lenses, $50 \mathrm{~mm}$ and $35 \mathrm{~mm}$. I also used medium formats, especially a Mamiya Press 6x9 which I still have-light, modular and great for landscapes.

Now, I go for portability. I currently work with compact cameras, a Lumix LX7 at the moment. It's the size of a pack of cigarettes; it's fast and delivers very, very good pictures. I also use my iPhone more and more, but I hate Instagram and other post- 
processing devices. It's just an ever-ready camera. Actually a few of the pictures in the show were made with an iPhone.

What filters or printing techniques do you use? Do you do your own printing and have your own dark room?

I used to do a lot of darkroom work-black and white, as color was beyond my technical and financial reach-and had become a competent printer, I think. But I'm so glad all this is over. The darkroom is a great place, it's also a big pain, let's face it. Today I use semi-professional printing services, which deliver the kind of work I need at very affordable cost.

Now, mind you I'm not into "fine printing." I like my prints to be balanced and clear, so I usually sharpen them and saturate some colors, most often reds, and that is about it. Black and white-which I don't do anymore-is a whole different ball game. It is much more difficult to print, although you now do find very satisfying labs. Ink jet prints are actually a good-albeit expensive-solution both in term of rendering and durability, and there are some amazing papers on the market for those.

I'd like to say a word here about digital photography. I must say it really was a major revolution for me. I am aware of all the problems and issues that it entails (after all, I'm an academic working on those very topics), but as a photographer it totally opened new worlds for me. Digital darkroom is great, and opens new possibilities for working and especially showing pictures.

Do you have any favorite photographs you've taken? Could you discuss and share two or three and explain why you think they work so well?

I will only speak here of the exhibition "American Icons." As I said earlier, I don't believe in the single miracle image, but more in groups of images creating an atmosphere. But as you are asking, I would pick up three pictures that are actually commentaries on the "photographic act." 


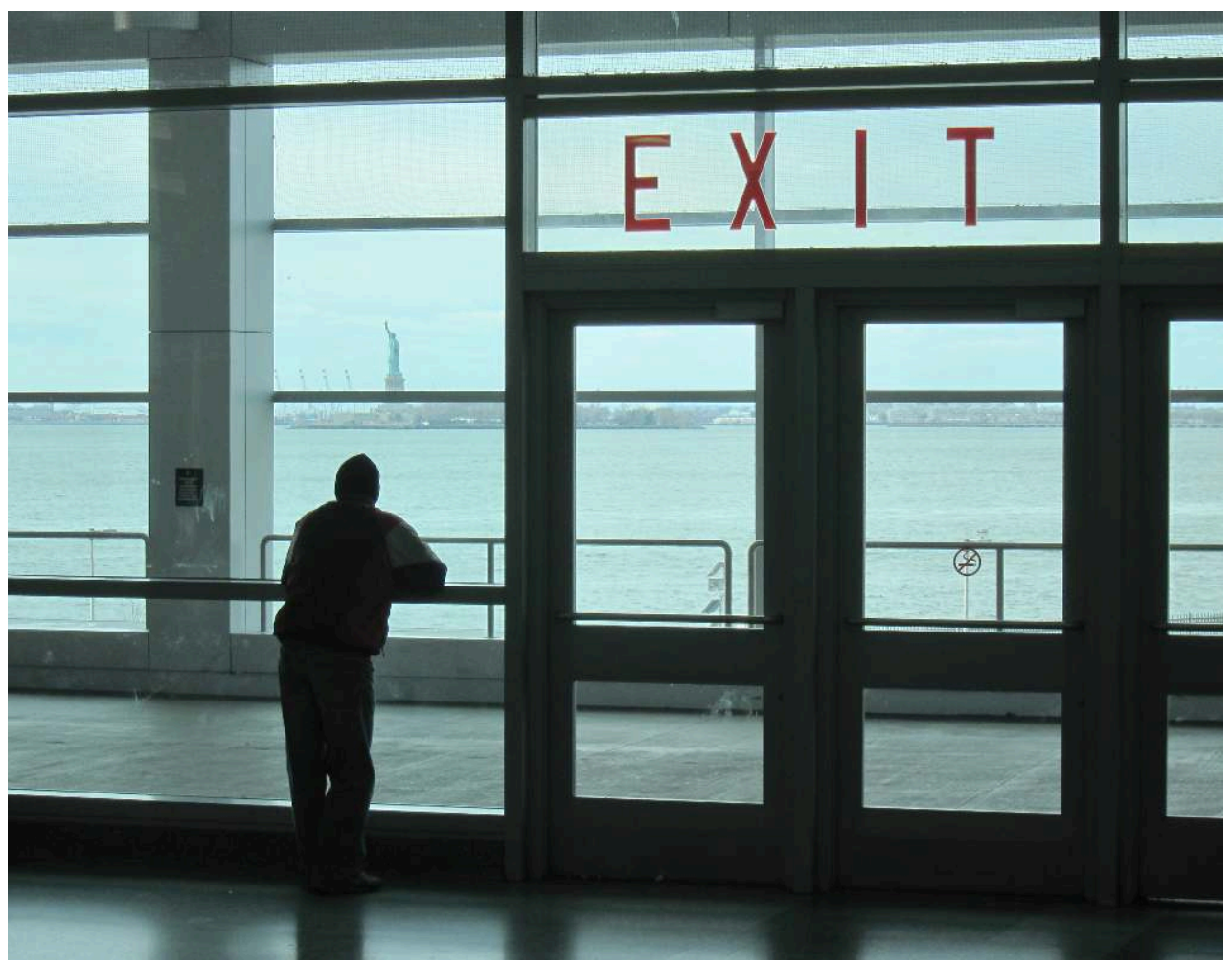

Jean Kempf, "Staten Island Ferry Terminal, New York, 2012"

I particularly like the man standing with the Statue of Liberty in the distance. With the "Exit" sign above the scene, the picture takes on a different meaning. It's not "true to the situation" (the man was actually waiting for the Staten Island ferry) but it says something about the "welcoming power" of the land of the free, and reminds us of the many men and women who actually emigrated from the US that we tend to forget. The photographer is a liar but he may say other things. 


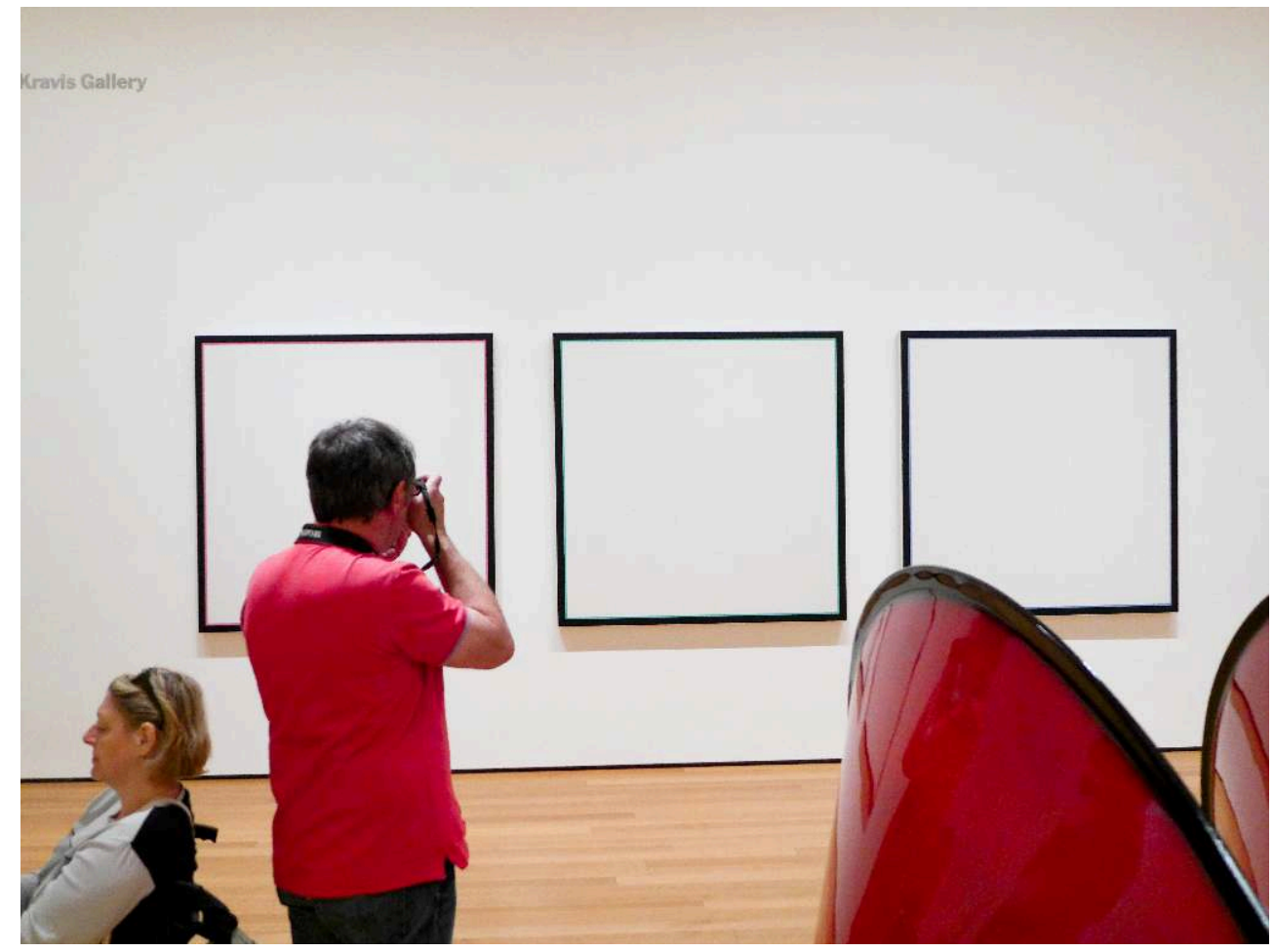

Jean Kempf, "MoMA, New York, 2013"

I also enjoyed making the picture of the man photographing three white canvases at the MoMA. I get really annoyed by people snapping pictures of paintings in museums, something smartphones have made viral. Sometimes friends ask me, "Why did you take that picture? I really don't understand!" Well, here, this man is taking a picture for reasons totally unknown to me, and even for reasons I would find stupid or absurd. So it's a way of commenting upon my own practice. After all, everybody has their reasons to take the pictures they take, so who am I to judge? 


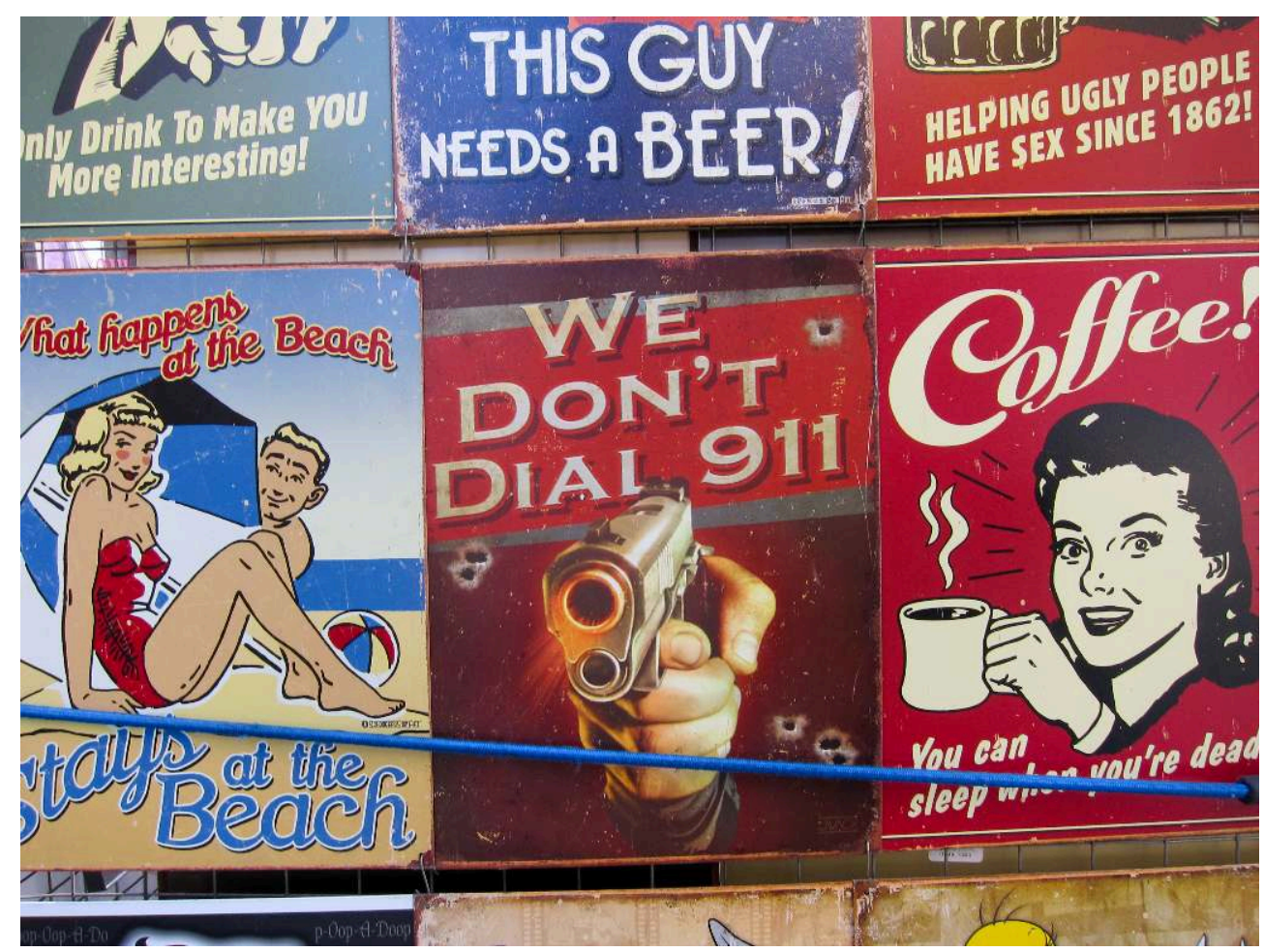

Jean Kempf, "Broadway, New York, 23 septembre 2012"

The last picture in the show may puzzle the viewers. It's the only one with a precise date. This is because it is highly autobiographical. After making this picture, I used it -albeit in a slightly cropped version-as what I believe was an innocuous attachment to professional e-mails I was exchanging with American colleagues. And it almost got me arrested and jailed as one of them took this image of an image (the "911" 1940s pulp illustration) as a direct menace to her. I don't think it evidences the power of images, but simply reflects on the fact that she interpreted it in a work context in which she felt threatened by me. So pictures are pictures only in context.

How does your faith, spirituality, or life philosophy affect your work?

I'm not sure I have any particular faith. And I'm not sure for me photography has anything to do with spirituality. No, the only thing that moves me when taking pictures is a deep love and respect for life and people. It's been for me a means of reaching out, of relating to the world, and I'm always amazed at how rich and bizarre the world is. To put it differently I would say that photography is a way for me to pause and look more deeply at things.

Is there a certain time of day or season of the year that you find most satisfying in terms of the overall approach you take to your photography?

When it's not too cold or too hot, because walking the streets by negative temperatures or sweltering heat is no fun!

Now with digital photography the flat, grey lights give out the best results, they turn out to be much more descriptive. In fact the best photographic light is not necessarily the light you like best as a viewer in actual life.

Are you terribly influenced by American folklore and history, and if so, how?

I'm first and foremost a student of American photography and a scholar of American cultural history. So American life and history have undoubtedly a big effect on me, 
not necessarily a conscious one (I don't go about ruminating about it in an intellectual way). I would say that I look at the American scene both as an outsider and an insider because of my familiarity with the issues.

Actually the US "scene" is so much mediatized by photographs (and by movies/series as well) that one cannot but see it through that filter, which can sometimes be a problem.

What are some of the techniques you use to capture motion?

I don't and I'm not good at it. When I worked as a photojournalist, I covered a lot of sports events. It was generally pretty bad...

Your photographs have a ruminative feeling to them. Why is that so appealing to you?

Ruminating? I didn't see it that way. Maybe because many question the thick history that came before them and are a form of meditation upon it? I'm someone who can get extremely excited about details I pick out while walking or driving. Details give you access to humanity, and by that I mean the individuality of people despite the societal formatting that each of us is the product of. And they make individuals not necessarily more lovable but at least more respectable. There's nothing I find more "human"-I say human for lack of a better word-than a slight problem with a woman's make up, a slightly frayed suit, or a not-quite-jointing wall. Those little imperfections redeem us as it were.

You work both with still life as well as portraiture. Is there one you prefer over the other?

I actually like both. One practice I have almost completely abandoned is street photography, catching people unaware, as it were. I would say that I find it psychologically more difficult, and also less meaningful. Doing portraiture is a way of engaging with a subject, and so is a still life. And that is what photography means to me, engaging with "the other." After all, you live with yourself all the time, so why keep doing it with a camera? You don't need it, do you? I'm not into self-portrait, or selfies, or the like. I find it useless and actually a little pathetic.

What are the challenges of each?

Well, portraits are challenging, much more so than still lives. Because it requires a combination of technical expertise and emotional awareness all in a very fast, compact, time frame.

Can you tell us about your future projects or exhibitions?

I am working on my old negatives, digitizing some. I want to reconstruct two exhibitions I did in my late teens, one on trains-essentially travelling on the OrientExpress from France to Istanbul-and one on life in a small circus-where I worked before going to college.

I'm also poring over my US/Canada files dating back to the 1970s.

And eventually I will build a photo site to showcase the work. I'm lucky to have a job, and that I don't need to make a living with my images, a thing which is becoming harder and harder.

But I do work on my pictures very seriously, and I think it's now become part and parcel of my activity. It's actually good to have reached a point in your academic career when you can do those things without calculating if that is significant for your $\mathrm{CV}$. Which is my case now. 
What do you think your photographic legacy will be?

I'm (obviously) passing on this.

INDEX

Subjects: Trans'Arts

AUTHOR

VICTORIA AMADOR

University of Sharjah (Arab Emirates) 